\title{
TRAF6 wt Allele
}

National Cancer Institute

\section{Source}

National Cancer Institute. TRAF6 wt Allele. NCI Thesaurus. Code C52447.

Human TRAF6 wild-type allele is located in the vicinity of $11 \mathrm{p} 12$ and is approximately 21 $\mathrm{kb}$ in length. This allele, which encodes TNF receptor-associated factor 6 , plays a role in the mediation of signaling from a variety of cellular receptors. 